\title{
Особливості психосоціальної адаптації студентів медичного коледжу, що перенесли психоемоційний стрес
}

\author{
A.I. Шарун \\ Дніпровський державний медичний університет, Дніпро, Україна
}

Анотація. 3 метою верифікації клініко-статистичних особливостей дезадаптаційних розладів у студентів-медиків, що перенесли психоемоційний стрес, на базі базового медичного коледжу за допомогою письмового структурованого інтерв'ю, клініко-психопатологічного та психометричного методів обстежена суцільна вибірка - 63 студенти віком 18-43 роки. Під час психометричного дослідження використані Шкали психологічного благополуччя (Ryff C.D., 1989; адаптовано Шевеленковою Т.Д., Фесенко П.П., 2005), астенічного стану (Малкова Л.Д.; адаптовано Чортовою Т.Г. на основі Міннесотського багатоаспектного особистісного опитувальника (Minnesota Multiphasic Personality Inventory - MMPI), опитувальник Леонгарда - Шмішека (Schmieschek H., 1970), Інтегративний тест тривожності (Бізюк А.П. та співавт., 2005). При аналізі отриманих даних виявлено, що специфічним та найчастішим проявом невротичних розладів студентів, що піддалися психоемоційному стресу, є ситуаційно-обумовлені реакції психічної дезадаптації. Відмічали підвищену стомлюваність, дратівливість, емоційну напруженість і лабільність, афективні розлади, порушення нічного сну, головний біль, вегетативні дисфункції. Виявлені порушення мали свою динаміку і формувалися в тісному зв'язку зі стресогенними факторами. Для зниження ризику формування непсихотичних психічних захворювань у рамках первинної та вторинної психопрофілактики необхідне проведення лонгітудинальних спостережень.

Ключові слова: розлади адаптації, тривога, астенія, психологічне благополуччя, стрес, студенти.

\section{Вступ}

Адаптація до стресу - одна з фундаментальних проблем медицини сьогодення [1, 2]. Увага до цієї проблеми обумовлена змінами, що відбуваються в даний час у процесі психіатричної парадигми з нозоцентричної на адаптаційну, відповідно до якої здоров'я загалом, а зокрема психічне здоров'я, розглядається як динамічний комплексний стан адаптації на біологічному, психологічному і соціальному рівнях функціонування, при цьому будь-які порушення адаптаційного процесу відіграють істотну роль у патогенезі більшості психічних розладів [3-6].

Порушення психічної адаптації під впливом різноманітних і множинних стресових факторів може з високою ймовірністю призвести до невротичних або психосоматичних розладів з клінічно окресленою симптоматикою [7]. Однак у більшості випадків порушення психічної адаптації виступають як донозологічний (субкліничний) стан або стан передхвороби, що мають схожу симптоматику з невротичними і неврозоподібними розладами, які позначено у Міжнародній класифікації хвороб X перегляду розділом F43 та іншими (F45, F48 та ін.). Незважаючи на те що приграничні нервово-психічні розлади $\epsilon$ перехідними від здоров'я до хвороби і ще не можуть вважатися патологією, вони істотно позначаються на психічному складі особистості, на можливості її цілеспрямованого реагування.

Сучасне суспільство характеризується етапом серйозних змін і вимог по відношенню до майбутніх молодих фахівців. Важливість виявлення депресивних і тривожних симптомів у студентів обумовлена темпом і напруженістю навчання, що висуває підвищені вимоги до компенсаторних механізмів психіки, зрив яких призводить до соціальних і психологічних конфліктів і стресу [8].

Специфіка навчання у закладі вищої освіти збігається з віком найвищого ризику маніфестації психічної патології, що, можливо, обумовлено не тільки біологічною природою психічних захворювань, але й значними стресовими навантаженнями $[9,10]$. Навантаження, характерні для навчання у медичному закладі освіти, створюють додаткові умови для маніфестації і схильності до захворювання. Здоровий спосіб життя - один із наріжних принципів сучасної медицини, формується у медичних працівників з моменту початку їх професійної освіти у медичних закла- дах вищої освіти і коледжах. Погіршення фізичного та психічного здоров'я студентів, що констатується останнім часом, зниження стресостійкості та когнітивних функцій стало предметом спеціальної уваги дослідників [11, 12].

Українська медична система освіти, яка останнім часом орі$\epsilon$ нтується на європейські стандарти якості життя, приділяє значну увагу цьому питанню. Однак специфіка освітнього процесу у медичних закладах (висока інтенсивність подачі інформації, велика кількість занять на день, необхідність постійних переїздів з однієї клініки в іншу за короткий проміжок часу) в сукупності із загальним зниженням рівня життя призводять до того, що більшість студентів-медиків особисто не дотримуються основ здорового способу життя [13].

Вирішення завдань пошуку закономірностей і механізмів адаптації студентів до навчання у закладі вищої освіти неминуче призводить до необхідності аналізу всього комплексу факторів, що визначають особливості навчальної діяльності студентів [14].

Розуміння закономірностей формування психосоціальної дезадаптивної поведінки у молоді з непсихотичними психічними розладами, рання діагностика порушень психосоціальної адаптації, ефективна реабілітація та психопрофілактика дозволять вирішити актуальне завдання сучасної психіатрії, медичної психології - запобігти порушенням працездатності, соціального функціонування та зниженню якості життя [15, $16]$.

Підхід до вирішення цієї проблеми повинен ґрунтуватися на принципах системності, комплексності та етапності з урахуванням індивідуальних особливостей осіб, що піддалися психоемоційному стресу [17].

Мета: клініко-статистичний аналіз психопатологічних особливостей дезадаптаційних розладів у студентів медичного коледжу, що перенесли психоемоційний стрес.

\section{0б'єкт і методи дослідження}

Проведено комплексне клініко-анамнестичне, клінікопсихопатологічне та психометричне обстеження. Відбір студентів для включення у дослідження проходив на базі Дніпровського базового медичного коледжу і включав декілька етапів. 
На I етапі у процесі скринінгу виділена основна група, в неї включали студентів, які мали в анамнезі значущий психоемоційний стрес.

На II етапі вивчали характерологічні особливості, соматичний статус і соціально-демографічні характеристики студентів (пільгові категорії, соціальні стипендії за категоріями внутрішньо переміщених осіб, діти учасників Антитерористичної операції (ATO), діти шахтарів та ін.) досліджуваних груп.

На III етапі сформовані основні групи ризику. Виключали неповнолітніх, осіб з розладами психотичного рівня (як в анамнезі, так і на момент обстеження), поточними органічними захворюваннями центральної нервової системи і тяжкою соматичною патологією.

Крім того, враховували найбільш вагомий стресогенний фактор за останні 5 років, відомості про звернення за психологічною допомогою, вживання заспокійливих препаратів.

Участь була добровільною, всі студенти давали добровільну інформовану згоду на процедуру дослідження. Анкетування проводили за допомогою авторської анкети у формі письмового структурованого інтерв'ю з дотриманням принципів біоетики і деонтології. Респондентам гарантували анонімність.

Оцінку психічного стану проводили на підставі структурованого клінічного інтерв'ю. Застосовували:

- Шкалу психологічного благополуччя (Ryff C.D., 1989; адаптована Шевеленковою Т.Д., Фесенко П.П., 2005);

- Опитувальник Леонгарда - Шмішека (Schmieschek H., 1970);

- Опитувальник вираженості психопатологічної симптоматики (Symptom CheckList-90-Revised) Derogatis L.R.; адаптовано Тарабріною Н.В., 2001);

- Шкалу астенічного стану (Малкова Л.Д.; адаптовано Чортовою Т.Г. на основі Міннесотського багатоаспектного особистісного опитувальника (Minnesota Multiphasic Personality Inventory - MMPI);

- Інтегративний тест тривожності (Бізюк А.П. та співавт., 2005);

- Опитувальник COPE (Carver C.S. et al., 1989).

Проведено аналіз даних рейтингових показників успішності та соціальної активності досліджуваних.

Основна група складалася із 33 студентів $(27(81,8 \%)$ жінок, 6 (18,2\%) чоловіків) віком 18-43 роки I-IV курсу навчання, що мали у анамнезі події, пов'язані зі значним стресом. Контрольна група сформована методом випадкового відбору і складалася із 30 студентів $(25$ (83,3\%) жінок, 5 (16,7\%) чоловіків) віком 18-32 роки без соматичних і психічних розладів, що не піддавалися дії психотравмувальних факторів.

Отримані дані зведені в електронну базу даних й оброблені в «Microsoft Office Excel 2007». Статистичний аналіз результатів дослідження виконували із застосуванням пакета прикладних статистичних програм «Statistica 6.0» («StatSoft, Inc.», США, 2003).

\section{Результати та їх обговорення}

У ході дослідження матеріалів, отриманих при використанні Шкали астенічного стану, в основній групі виявлено 9 (27,3\%) респондентів із результатом «слабка астенія», 2 (6,0\%) - «помірна астенія», у $22(66,7 \%)$ - астенія відсутня. У групі порівняння у 2 (6,7\%) респондентів виявлена «помірна астенія», у 28 (93,3\%) не відмічали явищ астенії. Серед основних скарг спостерігали надмірну дратівливість, нестійкість настрою, емоційну лабільність, зниження продуктивності психічних процесів, втрату здатності до тривалого розумового і фізичного навантаження.

Для індивідуального дослідження рівня психічної дезадаптації, а також аналізу основних факторів, що впливають на емоційний стан, використана методика «Інтегративний тест тривожності» (табл. 1). Проведена загальна оцінка тривоги і тривожності за ступенем їх вираженості поряд зі змістовним характером стану, що визначається тестом: емоційний дискомфорт, астенічний і фобічний компоненти, тривожна оцінка перспектив і соціальний захист.
Першою за величиною зрозумілої дисперсії серед допоміжних шкал особистісної тривожності стала шкала, що інтерпретується як «емоційний дискомфорт»: 30,3\% в основній групі та 3,3\% у групі контролю. У респондентів виявляли знижений емоційний фон або незадоволеність життєвою ситуацією, емоційну напруженість, елементи ажитації, безпосередньо чи опосередковано пов'язані з наявністю емоційних розладів.

Аналогічне відсоткове відношення виявлено за допоміжною шкалою «астенічний компонент тривожності»: 30,3\% в основній групі та 10,0\% - у контрольній. Факторні навантаження і результати спілкування з респондентами, які мають підвищені показники за цією шкалою, свідчать про переважання в структурі тривожності втоми, розладів сну, млявості, пасивності, швидкої стомлюваності.

Щодо ситуаційної тривожності, на перший план виходить допоміжна шкала «тривожна оцінка перспективи» $(24,2 \%$ в основній групі та 0\% - у контрольній), дуже чітко простежується проєкція страхів, обернена в перспективу, загальна заклопотаність своїм майбутнім на тлі підвищеної емоційної чутливості.

Наступна за питомою вагою - допоміжна шкала ситуаційної тривожності «фобічний компонент», що відображає картину емоційного фону випробовуваних з піком відчуття незрозумілої загрози, невпевненості у собі, власної непотрібності: $21,2 \%$ студентів 3 основної групи та 6,7\% - з групи контролю. Ці особи не завжди могли сформулювати джерело своїх тривог і в ході бесіди апелювали переважно до феноменології «хронічних» страхів, що періодично зростають залежно від внутрішнього стану або загострення зовнішньої ситуації. Тотожні результати виявлені за шкалою «астенічний компонент тривожності».

Загальні показники особистісної тривожності в основній групі (27,3\% порівняно з 3,3\% у групі контролю) свідчать про високий рівень тривоги, наявність дезадаптації в інтер- та інтраіндивідуальних відносинах і наявність дисгармонії з середовищем в цілому.

Загалом у ході діагностики за допомогою методики інтегративного тесту тривожності виявлені стани умовно патологічного типу, до яких належать порушення психічної адаптації. У основній групі розлади клінічно слабо структуровані, нестійкі, поліморфні, які не мають чіткої нозологічної приналежності, але мають чітку тенденцію до збільшення вираженості, перш за все у зв'язку зі змінами життя населення в нашій країні.

За допомогою Опитувальника Леонгарда - Шмішека встановлено, що кількість студентів в основній групі з акцентуацією становить 21 (63,6\%). Серед обстежених з виявленими акцентуаціями найбільшу групу становили особи із застрягаючим 9 $(27,2 \%)$ та емотивним $8(24,2 \%)$ типами акцентуації. Кількість студентів з екзальтованим типом акцентуації становила 7 (21,2\%), гіпертимним - 6 (18,2\%). Кількість осіб з акцентуацією циклотимного типу становила $4(12,1 \%)$, тривожного, демонстративного та збудливого - по 2 (6,1\%). Педантичний тип виявлено у 1 (3,0\%), дистимічний - ще у 1 (3,0\%) студента (рисунок).

Рисунок Типи акцентуації особистості в основній групі обстежених студентів медичного коледжу

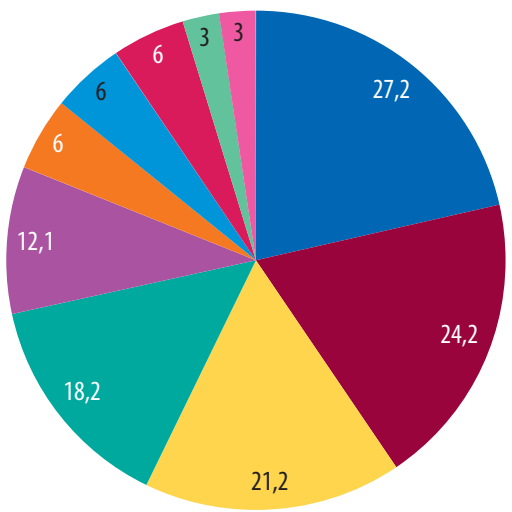

— Застрягаючий тип

- Емотивний тип

Екзальтований тип

— Гіпертимний тип

- Циклотимний тип

- Тривожний тип

- Демонстративний тип

- Збудливий тип

Педантичний тип

Дистимічний тип 
Таблиця 1 Загальні показники тривожності обстежених студентів медичного коледжу за методикою «Інтегративний тест тривожності»

\begin{tabular}{|c|c|c|c|c|c|c|c|c|}
\hline \multirow{3}{*}{ Шкала } & \multicolumn{4}{|c|}{ Ситуаційна тривожність } & \multicolumn{4}{|c|}{ Особистісна тривожність } \\
\hline & \multicolumn{2}{|c|}{ Основна група } & \multicolumn{2}{|c|}{ Контрольна група } & \multicolumn{2}{|c|}{ Основна група } & \multicolumn{2}{|c|}{ Контрольна група } \\
\hline & $\begin{array}{c}\text { Абсолютний } \\
\text { показник }\end{array}$ & $\%$ & $\begin{array}{c}\text { Абсолютний } \\
\text { показник }\end{array}$ & $\%$ & $\begin{array}{c}\text { Абсолютний } \\
\text { показник }\end{array}$ & $\%$ & $\begin{array}{c}\text { Абсолютний } \\
\text { показник }\end{array}$ & $\%$ \\
\hline Емоційний дискомфорт & 2 & 6,1 & - & - & 10 & 30,3 & 1 & 3,3 \\
\hline Астенічний компонент & 7 & 21,2 & 1 & 3,3 & 10 & 30,3 & 3 & 9,9 \\
\hline Фобічний компонент & 7 & 21,2 & 2 & 6,6 & 6 & 18,2 & 1 & 3,3 \\
\hline Тривожна оцінка перспективи & 8 & 24,2 & - & - & 7 & 21,2 & 1 & 3,3 \\
\hline Соціальний захист & 4 & 12,1 & 1 & 3,3 & 3 & 9,0 & - & - \\
\hline Загальний показник & 5 & 15,1 & - & - & 9 & 27,3 & 1 & 3,3 \\
\hline
\end{tabular}

Таблиця 2 Результати психометричного обстеження за допомогою Шкали психологічного благополуччя

\begin{tabular}{|c|c|c|c|c|c|c|c|c|c|c|c|c|}
\hline \multirow{3}{*}{ Шкала } & \multicolumn{4}{|c|}{ Низькі показники } & \multicolumn{4}{|c|}{ Середні показники } & \multicolumn{4}{|c|}{ Високі показники } \\
\hline & \multicolumn{2}{|c|}{ Основна група } & \multicolumn{2}{|c|}{ Контрольна група } & \multicolumn{2}{|c|}{ Основна група } & \multicolumn{2}{|c|}{ Контрольна група } & \multicolumn{2}{|c|}{ Основна група } & \multicolumn{2}{|c|}{ Контрольна група } \\
\hline & n & $\%$ & $\mathbf{n}$ & $\%$ & $\mathbf{n}$ & $\%$ & $\mathrm{n}$ & $\%$ & $\mathrm{n}$ & $\%$ & $\mathbf{n}$ & $\%$ \\
\hline Позитивні відносини & 10 & 30,3 & 3 & 10,0 & 12 & 36,4 & 21 & 70,0 & 11 & 33,3 & 6 & 20,0 \\
\hline Автономія & 9 & 27,3 & 3 & 10,0 & 13 & 39,4 & 15 & 50,0 & 11 & 33,3 & 12 & 40,0 \\
\hline Управління середовищем & 10 & 30,3 & 2 & 6,6 & 13 & 39,4 & 18 & 60,0 & 10 & 30,3 & 10 & 33,3 \\
\hline Особистісний ріст & 9 & 27,3 & 1 & 3,3 & 14 & 42,4 & 25 & 83,3 & 10 & 30,3 & 4 & 13,3 \\
\hline Мета в житті & 7 & 21,2 & - & - & 16 & 48,5 & 18 & 60,0 & 10 & 30,3 & 12 & 40,0 \\
\hline Самоприйняття & 11 & 33,3 & 2 & 6,6 & 18 & 54,5 & 20 & 66,6 & 4 & 12,1 & 8 & 26,6 \\
\hline Баланс афекту & 7 & 21,2 & 3 & 10,0 & 16 & 48,5 & 21 & 70,0 & 10 & 30,3 & 6 & 20,0 \\
\hline Осмислення життя & 5 & 15,1 & 1 & 3,3 & 12 & 36,4 & 16 & 53,3 & 16 & 48,5 & 13 & 43,3 \\
\hline Людина як відкрита система & 11 & 33,3 & 3 & 10,0 & 8 & 24,2 & 12 & 40,0 & 14 & 42,4 & 15 & 50,0 \\
\hline Психологічне благополуччя & 11 & 33,3 & 1 & 3,3 & 10 & 30,3 & 19 & 63,3 & 12 & 36,36 & 10 & 33,3 \\
\hline
\end{tabular}

За результатами кожного обстеженого будували аналітичні діаграми, що дозволяють візуалізувати отримані дані щодо кожного випробуваного.

Розглядаючи детальніше інформацію, отриману за допомогою Шкали психологічного благополуччя, найчастіше виявлялись наступні низькі показники шкал. Респонденти найчастіше стикалися з проблемою незадоволеності собою, розчарованістю подіями свого минулого, відчували занепокоєння з приводу деяких особистих якостей, бажали бути не тим, ким він/вона $\epsilon$, відповідно до шкали «самоприйняття»: 33,3\% студентів основної групи та 10,0\% - групи контролю. Низькі бали за шкалою «Людина як відкрита система» (33,3\% респондентів основної групи, $10,0 \%$ - групи контролю) корелювали з нездатністю достатньо інтегрувати окремі аспекти свого життєвого досвіду, формувалося фрагментарне, недостатньо реалістичне сприйняття різних аспектів життя. Відзначали низькі значення за шкалою «Позитивні відносини» в основній групі (30,3\%), зокрема відсутність достатньої кількості близьких, довірливих відносин, труднощі у прояві теплоти, відвертості і турботи про інших людей, переживання власної ізольованості і фрустрованості. Загалом низькі показники психологічного благополуччя, які відмічали у 11 $(33,3 \%)$ студентів основної групи, зумовлені перевагою негативного афекту, загальним відчуттям власної нещасливості, незадоволеності власним життям (табл. 2).

При аналізі отриманих даних виявлено, що специфічним та найчастішим проявом невротичних розладів у студентів, що піддалися психоемоційному стресу, $є$ ситуаційно-обумовлені реакції психічної дезадаптації. Зазначені реакції за своєю структурою і психопатологічною симптоматикою виявлялися окремими, малодиференційованими, нестабільними, фрагментарними, недостатньо окресленими клінічними симптомами. Відмічали підвищену стомлюваність, дратівливість, емоційну напруженість і лабільність, афективні розлади, порушення нічного сну, головний біль, вегетативні дисфункції. Виявлені порушення мали свою динаміку і формувалися у тісному зв'язку із стресогенними факторами.

Отримані дані щодо психологічних проявів порушень адаптації студентів корелюють з даними вітчизняних дослід- ників [11, 18, 19], проте необхідні лонгітудинальні дослідження для визначення траєкторії симптомів, ризику і захисних факторів дезадаптаційних станів в майбутньому, особливо серед груп ризику, та впровадження заходів профілактики та корекції.

\section{ВисновКИ}

1. Отримані результати дослідження психопатологічних особливостей дезадаптаційних розладів у студентів медичного коледжу свідчать про наявність як соціальних, так і психологічних факторів формування порушення. 3 одного боку, певне психоемоційне навантаження, особливо на 1-му році навчання, формує довготривалу тривожну емоційну реакцію, про що свідчать дані за шкалою тривоги.

2. Незважаючи на те що для непсихотичних психічних розладів частіше характерні легка вираженість психопатологічної симптоматики і сприятливий перебіг, ці стани суттєво порушують соціальне функціонування студентів і призводять до навчальної дезадаптації.

3. Перспектива подальшого дослідження полягаєу з'ясуванні особливостей перебігу непсихотичних психічних розладів у групі студентів підвищеного ризику, розробці та впровадженні комплексу ефективних заходів психокорекції.

\section{Список використаної літератури/References:}

1. Ababkov V.A., Perret M. (2004) Adaptation to stress. Fundamentals of theory, diagnosis, therapy. Speech, St. Petersburg, 83 p. (In Rus.).

2. Goldberger L., Breznitz S. (Eds.) (1993) Handbook of stress: Theoretical and clinical aspects (2nd ed.). Free Press.

3. Berezin F.B. (1988) Mental and psychophysiological adaptation of a person. Nauka, Leningrad, 267 p. (In Rus.).

4. Wasserman L.I., Ababkov V.A., Trifonova E.A. (2010) Coping with stress: theory and psychodiagnostics. Speech, St. Petersburg, 192 p. (In Rus.).

5. Wayne A.M. (1997) Clinical aspects of emotional stress. Emotional stress: theoretical and clinical aspects. Volgograd, 138-148 p. (In Rus.).

6. Sadock B.J., Sadock V.A., Ruiz P. (2015) Kaplan \& Sadock's synopsis of psychiatry: Behavioral sciences/clinical psychiatry (Eleventh ed.). Philadelphia, Wolters Kluwer. 
7. Novozhilova M.Yu. (2009) Psychodiagnostics in the system of clinical examination of persons with adjustment disorders due to stressful professional activity. Abstr. thesis ... dis. cand. psychol. sci. St. Petersburg, 234 p. (In Rus.).

8. Tajalli P., Ganbaripanah A. (2010) The relationship between daily hassles and social support on mental health of university students. Procedia. Social and Behavioral Science, 5: 99-103.

9. Proskuryakova L.A. (2012) Health Saving in Higher Education. Student health, (In Rus.).

10. Yur'eva L.M., Shornikov A.V., Shirokov O.V., Timofev R.M. (2020) Practical aspects of the mainstreaming of video science from the discipline "Psychiatry, narcology». Modern engineering and innovative technologies, 11(2): 62-68. (In Ukr.).

11. Kozhina G.M., Markova M.V., Grinevich E.G., Zelenska K.0. (2011) On the problem of adaptation syndrome of junior students of universities of III-IV levels of accreditation. Arch. Psychiatr., 4(67): 32-35. (In Rus.)

12. Kozhina G.M.,Humeniuk L.M., Zelenska K.0. (2011) Psychoprophylaxis of disorders of adaptation of freshmen to educational activity in a higher educational institution in the conditions of credit-modular system of education. Med. Psychol., 4(24): 78. (In Ukr.).

13. Nikolaenko 0.A., Gusakova I.V., Omelchenko 0.D., Bogomaz 0.V. (2017) The level of depression and anxiety among students studying at the Medical University of Ukraine. Juvenis sientia, 2: 13-15. (In Rus.).

14. Chaban 0.S., Haustova 0.0., Trachuk L.E. (2016) Ways to increase the effectiveness of teaching students in the specialty «Medical Psychology». Medical psychology, 1:3-8. (In Ukr.).

15. Gerasimenko L.0. (2018) Psychosocial maladaptation (modern conceptual models). Ukr. Bull. Psychoneurol., 26(1): 62-65. (In Ukr.).

16. Skripnikov A.M., Gerasimenko L.0., Isakov R.I. (2016) Psychosocial maladaptation in posttraumatic stress disorder in women. «ASMl» LLC, Poltava, 157 p. (In Ukr.).

17. Pinchuk I.Y., Babova K.D., Gozhenko A.I. (Eds.) (2014) Stress and man: medical and psychological care for stress disorders. Kalita Publishing House LLC, Kyiv, 92 p. (In Ukr.).

18. Kioseva 0.V. (2016) Psychopathological characteristics of the emotional sphere in junior students. Ukr. Bull. Psychoneurol., 24(86): 60-63. (In Ukr.).

19. Khaustov M.M. (2019) Psychodiagnostic features of young people with adaptation disorders. ScienceRise. Medical science, 1: 45-47. (In Ukr.)

\section{Відомості про автора:}

Шарун Анастасія Ігорівна - аспірант кафедри психіатрії, наркології і медичної психології Дніпровського державного медичного університету, Дніпро, Україна. ORCID ID: 0000-00020567-8799

Адреса для кореспонденції:

Шарун Анастасія Ігорівна

49044, Дніпро, вул. В. Вернадського, 9

E-mail:drsharunai@gmail.com

\section{Features of psychosocial adaptation of medical college students who have experienced psycho-emotional stress}

\section{A.I. Sharun}

Dnipro State Medical University, Dnipro, Ukraine

Abstract. In order to verify the clinical and statistical characteristics of maladjustment disorders in medical students who underwent psychoemotional stress, on the basis of a basic medical college using a written structured interview, clinical psychopathological and psychometric methods, a continuous sample was examined - 63 students aged 18-43. During the psychometric research, scales of psychological well-being were used (Riff C.D., 1989; adapted by T.D. Shevelenkova, P.P. Fesenko, 2005), asthenic state (Malkova L.D.; adapted by T.G. Chertova based on Minnesota Multiphasic Personality Inventory - MMPI), Leongard - Shmishek questionnaire (Schmieschek H., 1970), integrative test of anxiety (Bizyuk A.P. et al., 2005). When analyzing the data obtained, it was revealed that the specific and most frequent manifestation of neurotic disorders in students subjected to psychoemotional stress is situationally conditioned reactions of mental maladjustment. There was increased fatigue, irritability, emotional tension and lability, affective disorders, nighttime sleep disturbances, headache, and autonomic dysfunctions. The identified violations had their own dynamics and were formed in close connection with stress factors. To reduce the risk of the formation of nonpsychotic mental illness in the framework of primary and secondary psychoprophylaxis, longitudinal observation is required.

Key words: adjustment disorders, anxiety, asthenia, psychological well-being, stress, students.

\section{Information about the author:}

Sharun Anastasiia I. — postgraduate student of the Department of psychiatry, narcology and medical psychology of the Dnipro State Medical University, Dnipro, Ukraine. ORCID ID: 00000002-0567-8799

Address for correspondence:

Anastasiia Sharun

49044, Dnipro, V. Vernadsky st., 9

E-mail:drsharunai@gmail.com 